\title{
Probiotic Potential, Iron and Zinc Bioaccessibility, and Sensory Quality of Uapaca kirkiana Fruit Jam Fermented with Lactobacillus rhamnosus Yoba
}

\author{
Armistice Chawafambira $\mathbb{D D}^{1}{ }^{1}$ Moosa Mahmood Sedibe, ${ }^{1}$ Augustine Mpofu, ${ }^{2}$ \\ and Matthew Achilonu ${ }^{3}$ \\ ${ }^{1}$ Department of Agriculture, Faculty of Health and Environmental Sciences, Central University of Technology Free State, \\ Bloemfontein 9300, Private Bag X 20539, South Africa \\ ${ }^{2}$ Department of Food Science and Technology, Chinhoyi University of Technology, Private Bag 7724, Chinhoyi, Zimbabwe \\ ${ }^{3}$ Technology Section in Chemical, Mangosuthu University of Technology, Private Bag X 12363, Jacobs, Durban 4026, South Africa
}

Correspondence should be addressed to Armistice Chawafambira; achawazie@gmail.com

Received 9 June 2020; Revised 8 December 2020; Accepted 11 December 2020; Published 24 December 2020

Academic Editor: Amarat (Amy) Simonne

Copyright (c) 2020 Armistice Chawafambira et al. This is an open access article distributed under the Creative Commons Attribution License, which permits unrestricted use, distribution, and reproduction in any medium, provided the original work is properly cited.

Uapaca kirkiana is an underutilised indigenous fruit tree (IFT) found in the miombo ecological zone in sub-Saharan Africa. Furthermore, sub-Saharan Africa is home to many nutritionally insecure people who suffer from micronutrient deficiency. The incorporation of probiotic strains in jams as a possible way of enhancing mineral accessibility, food quality, and health is limited in Africa. This study monitored the probiotic potential, bioaccessible iron and zinc, and organoleptic properties of U. kirkiana fruit jam fermented with L. rhamnosus yoba. U. kirkiana fruits were collected from semiarid rural areas of Zimbabwe. The $L$. rhamnosus yoba strain was obtained from the Yoba for Life Foundation, Netherlands. Mineral and biochemical properties of the probiotic jam were analysed using AOAC standard methods. The U. kirkiana fruit tree was ranked first as a food resource by most rural populations in Zimbabwe. The probiotic jam formulation had 55\% (wt/vol) U. kirkiana fruit pulp, 43\% (wt/vol) sugar, $1.25 \%(\mathrm{wt} / \mathrm{vol})$ pectin, $0.5 \%(\mathrm{wt} / \mathrm{vol})$ citric acid, and $0.25 \%(\mathrm{wt} / \mathrm{vol})$ L. rhamnosus yoba strain. The probiotic jam had 6.2 $\pm 0.2 \log \mathrm{CFU} / \mathrm{mL}$ viable $L$. rhamnosus yoba cells. Iron and zinc content (mg/100 g w.b.) was $4.13 \pm 0.22$ and $0.68 \pm 0.02$ with $\mathrm{pH} 3.45 \pm 0.11$, respectively. Nutrient content was g/100 g w.b., carbohydrate $66 \pm 4.1$, fat $0.1 \pm 0.01$, crude protein $0.2 \pm 0.01$, ash $0.7 \pm 0.02$, and crude fiber $0.3 \pm 0.01$. Bioaccessible iron and zinc were $6.55 \pm 0.36 \%$ and $16.1 \pm 0.50 \%$ and increased by $4 \%$ and $2 \%$ in the probiotic jam, respectively. Mineral bioaccessibility and nutrient content were significantly different $(p<0.05)$ in jam with $0.25 \%$ L. rhamnosus yoba. Jam acceptance rating was $83 \%$. The probiotic jam can be used as a sustainable food containing probiotic with potential nutritional and health benefits.

\section{Introduction}

Uapaca kirkiana belongs to the genus Uapaca of the family Euphorbiaceae and subfamily Phyllanthaceae $[1,2]$. The Uapaca kirkiana fruit tree is an underutilised indigenous fruit tree (IFT) that is well-adapted to the miombo ecological zone in sub-Saharan Africa [3]. The U. kirkiana tree is distributed in semidry and hot areas although it can grow in some relatively wet regions of Zimbabwe [4]. The tree produces fruits which ripen from October to February.
The U. kirkiana fruit is a good source of sugar, energy, and essential minerals [5-7]. Chawafambira et al. [4] reported that the fruit pulp contains $\mathrm{Fe}(11.8 \mathrm{mg} / 100 \mathrm{~g}$ FW), Zn (1.3 mg/100 g FW), Ca (17 mg/100 g FW), Mg $(39 \mathrm{mg} / 100 \mathrm{~g} \mathrm{FW})$, and $\mathrm{K}(375 \mathrm{mg} / 100 \mathrm{~g} \mathrm{FW})$. Furthermore, Stadlmayr et al. [8] reported the proximate composition of the fruit as water $(72.6 \mathrm{~g} / 100 \mathrm{~g})$, carbohydrates $(28.7 \mathrm{~g} / 100 \mathrm{~g})$, proteins $(0.5 \mathrm{~g} / 100 \mathrm{~g})$, fat $(0.4 \mathrm{~g} / 100 \mathrm{~g})$, calories $(523 \mathrm{kcal} / \mathrm{kJ})$, ash $(1.1 \mathrm{~g} / 100 \mathrm{~g})$, fiber $(2.3 \mathrm{~g} / 100 \mathrm{~g})$, and vitamin C $(16.8 \mathrm{mg} / 100 \mathrm{~g})$. 


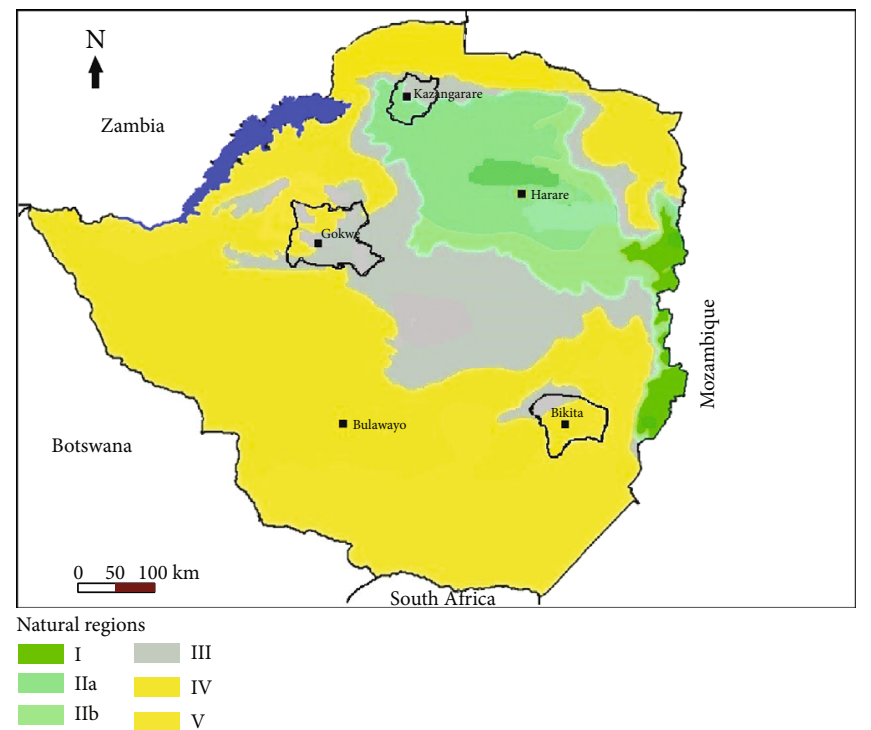

Figure 1: Map showing sampling areas (Bikita, Gokwe, and Kazangarare) of U. kirkiana fruits in Zimbabwe.

Bioaccessibility refers to a nutrient fraction that is released from the food matrix and available for absorption in the small intestine $[9,10]$. Currently, in vitro assays are mainly used to evaluate mineral bioaccessibility in foods [10] using a simulation model of the digestion process [11]. There is evidence of enhanced bioaccessibility of iron from plant foods caused by household food processing techniques such as heat treatment and fermentation [12]. Fermented foods have a low risk of contamination and provide new desirable taste and texture to food. Fermented products and the contribution of microorganisms provide essential nutrition and health. Fermentation is applied to release the complexed minerals and enhances their bioaccessibility and bioavailability [13]. Food fermentation results in dephytinization leading to increased bioaccessibility and bioavailability of magnesium, iron, calcium, and zinc content [13].

Deficiencies of micronutrients, especially iron and zinc, are nutritional problems that occur the most all over the world [12] and are widely prevalent in most developing countries [10]. Micronutrient deficiencies are often referred to as "hidden hunger" because they are less visible than macronutrient deficiencies [12]. Iron is essential in the synthesis of haemoglobin and myoglobin [14]. Zinc is important in gene regulation and apoptosis [15]. Iron and zinc absorption occurs in the small intestines [16].

Probiotics have been reported to produce short chain fatty acids, which increase the solubility of available calcium [17]. Research by Villa et al. [18] indicated an increase in calcium bioavailability by the action of probiotics such as Lactobacillus and Bifidobacterium in the hydrolysis of glycoside bonds of estrogenic food in the small intestines. Of late, in vitro bioaccessibility of iron and zinc has been conducted by solubility assays in fruit juices [14].

Many studies have reported the benefits of consuming $L$. rhamnosus GG in the prevention and treatment of upper respiratory tract infections, gastrointestinal infections, and diarrhoea in children [19-21]. The use of L. rhamnosus yoba could significantly change sensory attributes, preferences, and acceptability of food by consumers. Mattila-Sandholm et al. [22] noted that sensory aspects of probiotic foods are important in promoting the consumption of functional foods. The effect of L. rhamnosus yoba on the mineral bioaccessibility, sensory quality, and chemical properties of fruit jams has not been extensively investigated. Thus, the purpose of this study was to evaluate iron and zinc bioaccessibility and sensory qualities of probiotic U. kirkiana fruit jam fermented with L. rhamnosus yoba.

\section{Materials and Methods}

2.1. Study Area. Ripe U. kirkiana fruits were collected from Gokwe (a semidry area located $18.22^{\circ} \mathrm{S} 28.93^{\circ} \mathrm{E}$ in agro farming region 3 ), Bikita (a dry area located $20.5^{\circ} \mathrm{S} 31.37^{\circ} \mathrm{E}$ in agro farming region 4), and Kazangarare (a communal area located $16.30^{\circ} \mathrm{S} 29.56^{\circ} \mathrm{E}$ in agro farming regions $2 \mathrm{~b}$ and 3 ) as shown in Figure 1.

2.2. Field Data Collection. Permission to obtain fruit samples was obtained from local leaders (councillors), and consent forms were obtained from participating households.

2.3. Focus Group Discussions and Interviews. Focus group discussions and interviews were conducted in the local Shona language for better understanding by all participants. Semistructured questionnaires were used in formal interviews of indigenous people to understand their perceptions on preferences, availability, uses, and consumption of indigenous fruit trees (IFTs). This was important regarding the significance of the U. kirkiana fruit tree as a food resource as compared to other indigenous fruit trees. Data collected in focus group discussions and interviews included sociodemographic information such as age and gender. The importance of the $U$. kirkiana fruit as compared to other indigenous fruit trees as a food resource was evaluated by asking participants to rank 


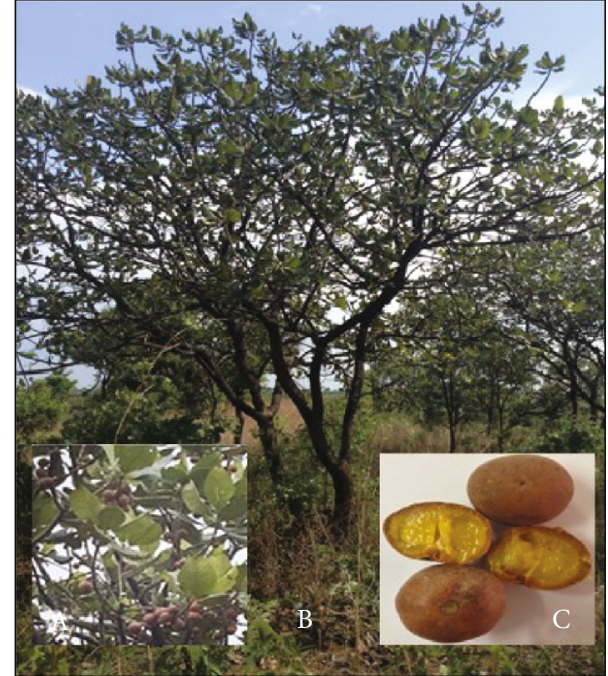

FIgURE 2: U. kirkiana fruits (a), U. kirkiana fruit trees (b), and $U$. kirkiana fruit pulp and seed (c).

fruit trees in their area from the most important (ranked 1) to the least important (ranked 5). Data was collected on the consumption pattern and socioeconomic significance of the fruit trees in the areas.

2.4. Fruit Collection. Fruit trees were chosen randomly using stratified sampling method (Figure 2(b)). Each ward in an area was considered a strata, and a total of 5 wards were considered. Samples of 100 ripe fruits that had fallen from different parts of the tree were randomly collected from the ground (Figure 2(a)). A total of 1000 fruits with a total mass of $8 \mathrm{~kg}$ were collected.

2.5. Pulp Extraction. Collected ripe fruits were cleaned, and soil particles and stones were removed. The edible pulp was obtained by cutting the fruit, removing seeds, then mashing, and sieving. The crude pulp mixture was sieved through an $800 \mu \mathrm{M}$ sieve to obtain a composite pulp sample.

2.6. Preparation of U. kirkiana Fruit Jam. The best formulation for making the fruit jam had 55\% (wt/vol) composite fruit pulp, 43\% (wt/vol) sugar, $1.5 \%$ (wt/vol) pectin, and $0.5 \%$ (wt/vol) citric acid. In producing the jam, the composite fruit pulp was mixed with sugar in a stainless steel pot and cooked at $110^{\circ} \mathrm{C}$ until all the sugar had dissolved. Citric acid $(0.5 \%)$ was added and stirred gently whilst cooking until it reached 55 Brix. Commercial pectin was added, and the mixture was continuously stirred until the jam had reached its end point of 68 Brix as indicated in Figure 3.

2.7. Source of L. rhamnosus Yoba. L. rhamnosus yoba was purchased from the Yoba for Life Foundation, Netherlands, and used in this study. This isolate, L. rhamnosus yoba, was obtained from a commercial product containing L. rhamnosus GG and was identified and confirmed using $16 \mathrm{~S}$ rRNA sequencing [21]. This isolate was deposited at the Belgian Coordinated Collections of Microorganisms/Laboratorium voor Microbiologie Gent (BCCM/LMG) culture collection

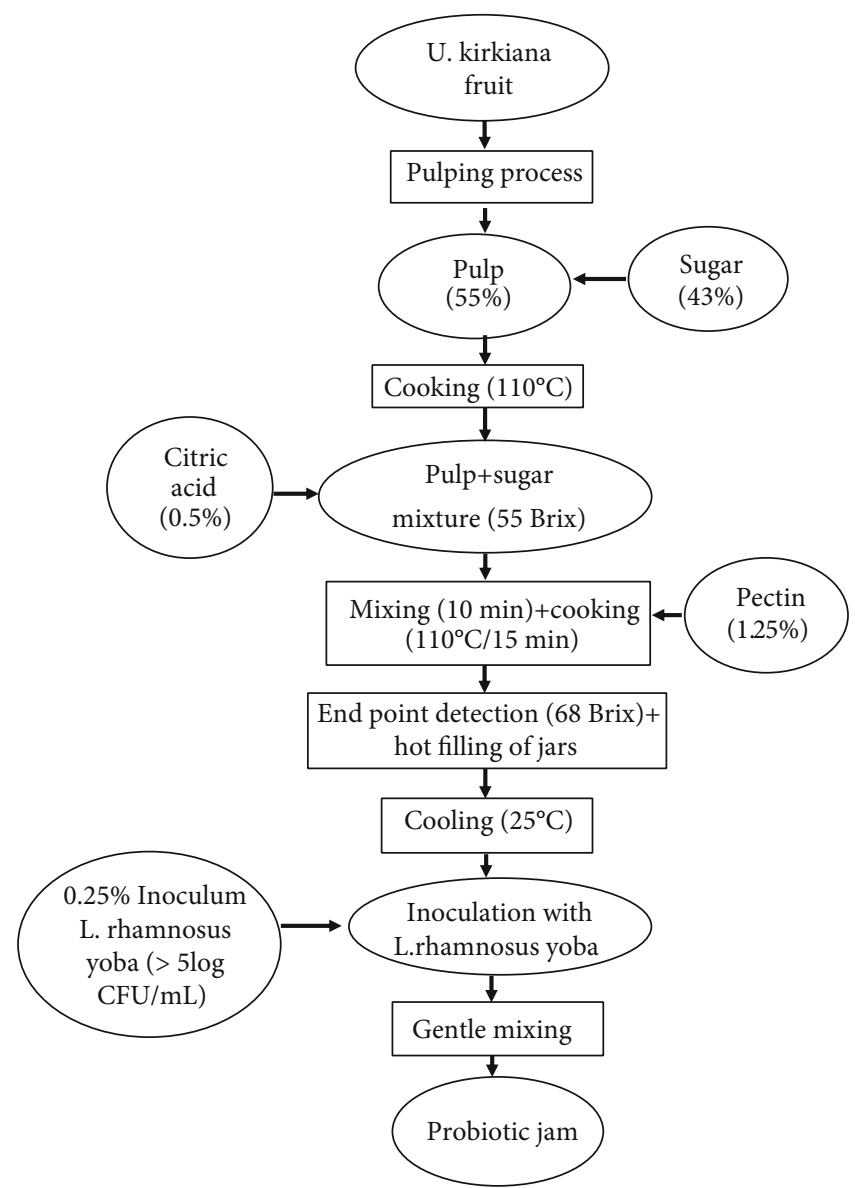

FIGURE 3: Production process of fruit jam inoculated with $L$. rhamnosus yoba.

using the name L. rhamnosus yoba. This isolate bacterium, L. rhamnosus yoba, was purchased and used in this study.

2.8. Preparation of Inoculum. Pure strains of L. rhamnosus yoba were obtained from the Yoba for Life Foundation, Amsterdam, Netherlands, and stored at $-80^{\circ} \mathrm{C}$. The L. rhamnosus yoba strain was reactivated by subculturing anaerobically in de Man, Rogosa, and Sharpe (MRS) agar broth at $37^{\circ} \mathrm{C}$ for 18 hours. The fruit pulp was mixed with sugar, boiled, and subsequently cooled to room temperature $\left(25^{\circ} \mathrm{C}\right)$. Five grams of $L$. rhamnosus yoba pure strain was then precultured in the medium and incubated at $37^{\circ} \mathrm{C}$ for 36 hours. Growth of the bacterium was monitored until the number of live cells was more than $6 \log \mathrm{CFU} / \mathrm{mL}$.

2.9. Inoculation of Probiotic Culture into the Jam. Sterilized bottles $(400 \mathrm{ml})$ containing $U$. kirkiana fruit jam $(100 \mathrm{~g})$ were opened under aseptic conditions, and the jam was inoculated with $2.5 \mathrm{~mL}$ of fresh probiotic culture. L. rhamnosus yoba cell suspensions of the culture were gently mixed with the jam. In the control experiment, distilled water $(2.5 \mathrm{~mL})$ was boiled, cooled to $30^{\circ} \mathrm{C}$, and inoculated into the fruit jam.

2.10. Determination of Growth Rate of L. rhamnosus Yoba. The growth rate of L. rhamnosus yoba in the jam was 
evaluated over a period of 24 hours. Sampling was done every $2 \mathrm{~h}$ over the $24 \mathrm{~h}$ period. One milliliter $(1 \mathrm{~mL})$ of a sample was aseptically taken from the jam and suspended in sterile $9 \mathrm{ml}$ of peptone physiological salt solution $(\mathrm{pH} 7.0,8.5 \mathrm{~g} / \mathrm{L} \mathrm{NaCl}$, and $1 \mathrm{~g} / \mathrm{L}$ neutralized bacteriological peptone from Oxoid). Diluents of $100 \mu \mathrm{L}$ were plated in triplicate onto de Man, Rogosa, and Sharpe (MRS) agar (1.2\% agar, bacteriological peptone from Oxoid, added to de Man, Rogosa, and Sharpe broth, Merck). MRS agar plates were incubated at $37^{\circ} \mathrm{C}$ under anaerobic conditions in GasPak anaerobic jars (Becton Dickinson Microbiology Systems, Baltimore, Maryland, USA). All colonies on the MRS agar were counted, and the results were expressed as colony forming units per milliliter $(\mathrm{CFU} / \mathrm{mL})$ of L. rhamnosus yoba, taking into account the dilution factors.

2.11. Iron and Zinc In Vitro Bioaccessibility Assay. Iron and zinc bioaccessibility were determined using the INFOGEST in vitro digestion protocol [23]. The initial iron and zinc content in the probiotic jam was measured before and after the oral, gastric, and intestinal phases of simulated gastrointestinal digestion.

2.11.1. Oral Phase. A jam sample of $5 \mathrm{~g}$ was mixed with $4 \mathrm{~mL}$ of simulated salivary fluid (SSF). To this sample, $0.95 \mathrm{~mL}$ of Milli-Q water was added, followed by the addition of $25 \mu \mathrm{L}$ of $\mathrm{CaCl}_{2}$ solution and $25 \mu \mathrm{L}$ of $\alpha$-amylase (75 units $/ \mathrm{mL}$ ). The resultant mixture was incubated for $2 \mathrm{~min}$ at $37^{\circ} \mathrm{C}$ in a shaking water bath.

2.11.2. Gastric Phase. In the simulated digestion phase, $7.5 \mathrm{~mL}$ of simulated gastric fluid (SGF), $1.6 \mathrm{~mL}$ pepsin solution (2000 units/mL), and $5 \mu \mathrm{L}$ of $\mathrm{CaCl}_{2}$ solution were added to the mixture from the oral phase. The $\mathrm{pH}$ of the mixture was adjusted to 3 by adding approximately $0.8 \mathrm{~mL}$ of $6 \mathrm{M}$ hydrochloric acid. The resultant mixture was incubated for $>2 \mathrm{~min}$ at $37^{\circ} \mathrm{C}$ in a shaking water bath.

2.11.3. Intestinal Phase. In the intestinal phase of simulated digestion, solutions were added in the following sequence to the mixture from the gastric phase; $11 \mathrm{~mL}$ of simulated intestinal fluid (SIF), $5 \mathrm{~mL}$ of pancreatin solution (100 units $/ \mathrm{mL}), 2.5 \mathrm{~mL}$ of bile solution $(10 \mathrm{mM})$, and $40 \mu \mathrm{L}$ of $\mathrm{CaCl}_{2}$. The $\mathrm{pH}$ of the mixture was adjusted to 7 by adding $1 \mathrm{M} \mathrm{NaOH}$ dropwise $(0.5 \mathrm{~mL})$, and the mixture was incubated for 2 hours at $37^{\circ} \mathrm{C}$ in a shaking water bath at $300 \mathrm{rpm}$. A sample of $1 \mathrm{~mL}$ was collected after simulated intestinal digestion and pipetted into capped microcentrifuge tubes. The sample was then analysed for the zinc and iron content.

2.12. Zinc and Iron Analyses. Iron and zinc content was determined using an Inductively Coupled Plasma-Optical Emission Spectrometer (ICP-OES) (Agilent 5100, Agilent Technologies, Santa Clara, California, USA), which allows for simultaneous detection of minerals [24]. Samples of the probiotic jam and/or intestinal phase sample were digested using concentrated solutions of nitric acid $\left(\mathrm{HNO}_{3}\right)$ and sulphuric acid $\left(\mathrm{H}_{2} \mathrm{SO}_{4}\right)$, followed by addition of ultrapure hydrogen peroxide $\left(\mathrm{H}_{2} \mathrm{O}_{2}\right)$ to complete the digestion. Residual samples were filtered off where necessary. The digested samples were then fed into the automated ICP-OES by vacuum-operated pipes, and results were recorded. Results were converted from ppm per $100 \mathrm{~g}$ to $\mathrm{mg}$ per $100 \mathrm{~g}$ fresh mass (FM) by dividing by 10 .

2.13. Iron and Zinc Bioaccessibility Calculation. Iron and zinc content results from the ICP-OES analysis were used to calculate the bioaccessibility of the minerals according to an equation adopted from Hemalatha et al. [25].

$$
\operatorname{Bioaccessibility}(\%)=100 \times \frac{Y}{Z} \text {, }
$$

where $Y$ is the element content of the bioaccessible fraction (mg mineral/100 g) and $Z$ is the total mineral (zinc or iron) content $(\mathrm{mg} / 100 \mathrm{~g})$.

2.14. Biochemical Analysis. Crude protein, fat, ash, and crude fiber content of the probiotic jam were determined according to Association of Official Analytical Chemistry [24] methods. Total carbohydrate content of probiotic jam was estimated by the difference method.

2.15. $\mathrm{pH}$ Measurement. The $\mathrm{pH}$ was determined according to the AOAC standard method using a digital $\mathrm{pH}$ meter (BT675 , BOECO, Hamburg, Germany). The glass electrode of the $\mathrm{pH}$ meter was calibrated using standard buffer solutions ( $\mathrm{pH} 4$ and $\mathrm{pH}$ 7) prior to $\mathrm{pH}$ measurements [26].

2.16. Sensory Evaluation Process. In the sensory evaluation process, 140 taste panels were selected using systematic random sampling. Demographic information about the taste panelists was collected. Consent forms were signed by each panelist. A sensory questionnaire using a 9-point hedonic scale and preference test was designed using Shona, a local language used by the panelists. The 9-point hedonic scale used the following key: 1: dislike extremely, 2: dislike very much, 3: dislike moderately, 4: Dislike slightly, 5: neither like nor dislike, 6: like slightly, 7: like moderately, 8: like strongly, and 9: like extremely; instructions for the panelists was translated in the local language for easy understanding of the sensory process. The panelists evaluated mouth feel, taste, aroma, texture, spreadability, and overall acceptance and rated their responses on the 9-point hedonic scale. A commercially made mixed fruit jam was used a benchmark product, and a paired preference test was used to compare the taste. Panelists were not allowed to discuss their results during the sensory evaluation process. Panelists were presented with a jam sample weighing $25 \mathrm{~g}$ each. Samples were served in small paper plates covered with aluminum foil.

2.16.1. Triangle Test. The ability of trained and untrained panelists to discriminate between probiotic jam samples and ordinary jam samples was calculated using a triangle test. The panelists were drawn from three areas, Gokwe (40), Bikita (40), and Kazangarare (40), and trained panelists were from the Department of Food Science and Technology, Chinhoyi University of Technology (20). Temporary sensory testing booths made of cardboard box were used by untrained panelists in Gokwe, Bikita, and Kazangarare. The jam samples were coded as $\mathrm{A} 1 \mathrm{~B}, 1 \mathrm{AB}, 1 \mathrm{BA}, \mathrm{B} 1 \mathrm{~A}, \mathrm{BA} 1$, and 
TABLE 1: Ranking of indigenous fruit trees (IFTs) as food resources by locals in Gokwe, Bikita, and Kazangarare, Zimbabwe.

\begin{tabular}{|c|c|c|c|c|c|}
\hline Local name & Botanical name & Family & Use & Rank & Consumption (\%) \\
\hline \multicolumn{6}{|l|}{ Gokwe communal area } \\
\hline $\begin{array}{l}\text { Wild loquat (Eng), mushuku/muzhanje (Sh), } \\
\text { umhobohobo (Nd) }\end{array}$ & Uapaca kirkiana & Euphorbiaceae & $\begin{array}{l}\text { Fruit eaten raw } \\
\text { without seeds }\end{array}$ & 1 & 70 \\
\hline $\begin{array}{l}\text { Monkey orange (Eng), mutamba (Sh), } \\
\text { umkhemeswane }(\mathrm{Nd})\end{array}$ & Strychnos cocculoides & Strychnaceae & Fruit eaten raw & 2 & 55 \\
\hline Bird plum (Eng), munyii (Sh), umnyiyi (Nd) & Berchemia discolor & Rhamnaceae & Fruit pulp eaten raw & 3 & 45 \\
\hline $\begin{array}{l}\text { Chocolate berry (Eng), mutsubvu (Sh), } \\
\text { umtshwankela (Nd) }\end{array}$ & Vitex payos & Lamiaceae & Fruit eaten raw & 4 & 40 \\
\hline Snot apple (Eng), mutohwe (Sh) & Azanza garckeana & Malvaceae & $\begin{array}{l}\text { Fruit is chewed raw } \\
\text { without seeds }\end{array}$ & 5 & 35 \\
\hline \multicolumn{6}{|l|}{ Kazangarare communal area } \\
\hline $\begin{array}{l}\text { Chocolate berry (Eng), mutsubvu (Sh), } \\
\text { umtshwankela (Nd) }\end{array}$ & Vitex payos & Lamiaceae & Fruit pulp eaten raw & 1 & 74 \\
\hline $\begin{array}{l}\text { Wild loquat (Eng), mushuku/muzhanje (Sh), } \\
\text { umhobohobo (Nd) }\end{array}$ & Uapaca kirkiana & Euphorbiaceae & Fruit eaten raw & 2 & 70 \\
\hline Bird plum (Eng), munyii (Sh), umnyiyi (Nd) & Berchemia discolor & Rhamnaceae & Fruit pulp eaten raw & 2 & 62 \\
\hline Snot apple (Eng), mutohwe(Sh) & Azanza garckeana & Malvaceae & $\begin{array}{l}\text { Fruit is chewed raw } \\
\text { without seeds }\end{array}$ & 3 & 47 \\
\hline $\begin{array}{l}\text { Monkey orange (Eng), mutamba (Sh), } \\
\text { umkhemeswane (Nd) }\end{array}$ & Strychnos cocculoides & Strychnaceae & Fruit eaten raw & 4 & 40 \\
\hline $\begin{array}{l}\text { Bakota plum (Eng); munhunguru (Sh), } \\
\text { umqokolo }(\mathrm{Nd})\end{array}$ & Flacourtia indica & Salicaceae & Fruit is eaten raw & 5 & 35 \\
\hline \multicolumn{6}{|l|}{ Bikita communal area } \\
\hline $\begin{array}{l}\text { Wild loquat (Eng), mushuku/muzhanje (Sh), } \\
\text { umhobohobo (Nd) }\end{array}$ & Uapaca kirkiana & Euphorbiaceae & Fruit eaten raw & 1 & 76 \\
\hline $\begin{array}{l}\text { Chocolate berry (Eng), mutsubvu (Sh), } \\
\text { umtshwankela (Nd) }\end{array}$ & Vitex payos & Lamiaceae & Fruit pulp raw & 1 & 60 \\
\hline $\begin{array}{l}\text { Monkey orange (Eng), mutamba (Sh), } \\
\text { umkhemeswane (Nd) }\end{array}$ & Strychnos cocculoides & Strychnaceae & Fruit eaten raw & 2 & 53 \\
\hline Bird plum (Eng), munyii (Sh), umnyiyi (Nd) & Berchemia discolor & Rhamnaceae & Fruit pulp eaten raw & 3 & 51 \\
\hline $\begin{array}{l}\text { Bakota plum (Eng), munhunguru (Sh), } \\
\text { umqokolo (Nd) }\end{array}$ & Flacourtia indica & Salicaceae & Fruit eaten raw & 4 & 48 \\
\hline Waterberry (Eng), mukute (Sh) & Syzygium cordatum & Myrtaceae & Fruit eaten raw & 4 & 45 \\
\hline Mobola plum (Eng), muhacha/muchakata (Sh) & Parinari curatellifolia & Chrysobalanaceae & Fruit pulp eaten raw & 5 & 36 \\
\hline
\end{tabular}

Key: Eng: English; Sh: Shona; Nd: Ndebele.

AB1. The coded samples were randomly given to each panelist together with a glass of water to rinse their mouth. The panelists were evaluated on their ability to discriminate differences in appearance and taste of the jam samples. The panelists who were able to discriminate the taste of the jam samples for both the trained and untrained panelists were used in the preference test.

2.16.2. Preference Test. Trained panelists were used to indicate their preference on sweetness, color, aroma, texture, and overall acceptance of the jams using a 9-point hedonic scale.

2.17. Statistical Analysis. The results of zinc and iron analyses, probiotic viability, $\mathrm{pH}$, and sensory properties were expressed as the mean \pm standard deviation (SD), and all experiments were conducted in triplicates. LSD test was conducted to determine any significant differences at $p<0.05$.
Customer acceptability and sensorial results were analysed using one-way Analysis of Variance (ANOVA). Probabilities for triangle taste tests were computed to analyse the triangular taste test data. All the analyses were done using SPSS package version 18.0 (Coakes and Ong, John Wiley \& Sons, Queensland, Australia).

\section{Results and Discussion}

The sample areas, Gokwe and Bikita, are farming communities in the semiarid and hot agroecological region of Zimbabwe. The U. kirkiana tree is well adapted to hot, dry areas [4]. Table 1 shows the importance of the U. kirkiana fruit tree as a food resource for the rural population in relation to other indigenous fruit trees (IFTs). The U. kirkiana was ranked first in Bikita and Gokwe, mainly because of its significant use and perceived nutritional benefits. Fruit pulp is eaten raw, and the seeds and skin are removed. U. kirkiana fruits 
TABLE 2: Mineral and nutrient content of probiotic and control fruit jam per $100 \mathrm{~g}$ wet basis.

\begin{tabular}{lcc}
\hline Nutrient (g) & $\begin{array}{c}\text { Probiotic jam (inoculated } \\
\text { with L. rhamnosus yoba) }\end{array}$ & Control \\
\hline Carbohydrates & $66.0 \pm 4.1^{\mathrm{a}}$ & $65.2 \pm 2.3^{\mathrm{b}}$ \\
Crude protein & $0.2 \pm 0.01^{\mathrm{a}}$ & $0.1 \pm 0.01^{\mathrm{b}}$ \\
Fat & $0.1 \pm 0.01^{\mathrm{a}}$ & $0.1 \pm 0.01^{\mathrm{a}}$ \\
Crude fiber & $0.3 \pm 0.01^{\mathrm{a}}$ & $0.1 \pm 0.01^{\mathrm{a}}$ \\
Ash & $0.7 \pm 0.02^{\mathrm{a}}$ & $0.4 \pm 0.01^{\mathrm{b}}$ \\
Minerals (mg) & & \\
Iron & $4.13 \pm 0.22^{\mathrm{a}}$ & $3.10 \pm 0.10^{\mathrm{b}}$ \\
Zinc & $0.68 \pm 0.02^{\mathrm{a}}$ & $0.42 \pm 0.01^{\mathrm{b}}$ \\
\hline
\end{tabular}

Mean \pm standard deviations are reported. Means with identical superscripts in a row are not significantly different at $p<0.05$.

are sold on the roadside and informal and formal markets to generate income. This observation was supported by Chawafambira et al. [4].

3.1. Chemical Composition. The nutrient content of the probiotic fruit jam in $\mathrm{g} / 100 \mathrm{~g}$ fresh weight basis was carbohydrate $66 \pm 4.1$, fat $0.1 \pm 0.01$, crude protein $0.2 \pm 0.01$, ash $0.7 \pm 0.02$, and crude fiber $0.3 \pm 0.01$ (Table 2 ). The probiotic jam is a good source of dietary iron and zinc and can possibly be used to supply these essential minerals in the body. Mineral deficiency is prevalent in most rural and urban areas in subSaharan Africa. Chawafambira et al. [4] reported that the $U$. kirkiana fruit is a good source of iron $(11.8 \mathrm{mg} / 100 \mathrm{~g})$, calcium $(17 \mathrm{mg} / 100 \mathrm{~g})$, potassium $(375 \mathrm{mg} / 100 \mathrm{~g})$, magnesium (39 $\mathrm{mg} / 100 \mathrm{~g})$, and phosphorus $(15 \mathrm{mg} / 100 \mathrm{~g})$. The high carbohydrate content makes the jam a good energy providing food.

3.2. Bioaccessible Iron and Zinc. Jam that was inoculated with L. rhamnosus yoba had an iron bioaccessibility of $6.55 \pm$ $0.36 \%$ (Table 3 ). Iron bioaccessibility was significantly different from that of the control jam $(p<0.05)$. Zinc bioaccessibility of the L. rhamnosus yoba jam was significantly different from that of the control jam $(p<0.05)$. The jam inoculated with $L$. rhamnosus yoba had a zinc bioaccessibility of 16.1 $\pm 0.50 \%$ (Table 4 ). Iron plays an important role in the human body, particularly in the formation of red blood cells. Iron bioaccessibility of probiotic (L. rhamnosus yoba) jam increased by $4 \%$ when the jam was inoculated with L. rhamnosus yoba. Zinc bioaccessibility in probiotic and control jams was $16.1 \pm 0.5 \%$ and $14 \pm 0.33 \%$, respectively. This translated to an increase of $2 \%$ in zinc bioaccessibility when L. rhamnosus yoba was inoculated into the jam. This could be attributed to the action of L. rhamnosus yoba as it produced degradation enzymes that acted on the food matrix to release the bound zinc.

Furthermore, the effect of processing during jam-making may cause the breakdown of complex polysaccharides from the food matrix under the action of pectinase to release the bound minerals. Khouzam et al. [27] reported a bioaccessibility of $6.7-12.7 \%$ for essential minerals in different fruits and vegetables. The bioaccessibility of iron might have been affected by the presence of inhibiting compounds such as phytates and carbonate salts during fruit maturation, which may chelate and form insoluble complexes with iron resulting in reduced iron bioaccessibility [27]. In its structure, phytic acid contains an inositol ring with 6 phosphate ester groups, and it chelates iron and zinc ions, forming insoluble complexes in the upper gastrointestinal tract [28]. These complexes cannot be digested or absorbed due to the absence of intestinal phytase enzymes in humans [29]. The analysis for phytic acid was not reported in this study, and this could not quantify the amount of phytic acid present in the jam; hence, an assumption was used explain its effect on the iron and zinc bioaccessibility. Furthermore, there is need to carry out an assay to determine the amount of phytic acid in the fruit pulp and jam.

U. kirkiana fruits contain organic acids such as malic and oxalic acids, and these might have complexed the iron and zinc during fruit maturation. Phenolic compounds in fruits reduce mineral bioaccessibility. The $U$. kirkiana fruit pulp had a total phenolic content of 67-82.5 $\mu \mathrm{g} \mathrm{GAE/g} \mathrm{[30].} \mathrm{The}$ presence of phenolic compounds in the fruit could explain the low bioaccessibility of iron.

Zinc is an essential micronutrient in the human body and is involved in many metabolic processes catalyzed by different enzymes. Its deficiency may lead to retarded growth and dermatitis [31]. The Zimbabwe Demographic and Health Survey (ZDHS) [32] report states the RDA for zinc and iron as 3-11 mg/100 g and $13-19 \mathrm{mg} / 100 \mathrm{~g}$, for age groups 1-9 years and 9-13 years, respectively. Therefore, calculations on \% contributions on RDA for essential minerals have indicated that the jam has a potential to deliver more than $20 \%$ and $30 \%$ of the RDA for iron and zinc in age groups 1-9 years and 9-13 years, respectively.

During the pulping process, the action of pectinase might have resulted in the release of zinc from the pectin matrix in the fruit pulp. The $U$. kirkiana fruit contains relatively high levels of calcium [4], and calcium has been found to inhibit the bioaccessibility of other minerals such as zinc [33]. Phytates that build up in the fruit pulp during the maturation process could have affected zinc bioaccessibility [34].

The possible mechanism by which L. rhamnosus yoba leads to increased mineral bioaccessibility and/or bioavailability was designed and represented by the author in Figure 4.

Conversely, the loss of dry matter during fermentation increases mineral content as lactic acid bacteria degrades sugar and protein [36]. L. rhamnosus yoba is capable of fermenting glucose into organic acids in the jam. The observed increase in iron content could be explained by the process of fermentation which degrades phytates that complex with minerals thereby releasing the iron and other minerals such as zinc, calcium, and phosphorous in the jam [35]. Lopez et al. [37] reported the importance of fermentation in reducing phytic acid that binds minerals and making them free and more bioaccessible and available for absorption in the human body. The probiotic, L. rhamnosus yoba, could have produced $\alpha$-amylase enzymes that loosen the food matrix by degrading starch. Liang et al. [38] reported that fermenting microorganisms are able to degrade fiber and loosen the 
TABLE 3: In vitro digestion on iron content of the jam inoculated with L. rhamnosus yoba.

\begin{tabular}{lcccc}
\hline & \multicolumn{2}{c}{ Iron content (mg/100 g FM) } & & \\
Sample & Undigested (total content) & After digestion & Bioaccessible portion & Bioaccessibility (\%) \\
\hline L. rhamnosus yoba jam & $4.13 \pm 0.22^{\mathrm{a}}$ & $3.86 \pm 0.14^{\mathrm{b}}$ & $0.27 \pm 0.08^{\mathrm{a}}$ & $6.55 \pm 0.36^{\mathrm{a}}$ \\
Control & $4.03 \pm 0.41^{\mathrm{a}}$ & $3.92 \pm 0.03^{\mathrm{b}}$ & $0.11 \pm 0.38^{\mathrm{b}}$ & $2.7 \pm 0.92^{\mathrm{b}}$ \\
\hline
\end{tabular}

Mean \pm standard deviations are reported. Means with identical superscripts in a column are not significantly different at $p<0.05$.

TABLE 4: In vitro digestion on zinc content of the jam inoculated with L. rhamnosus yoba.

\begin{tabular}{lcccc}
\hline & \multicolumn{2}{c}{ Zinc content (mg/100 g FM) } & & \\
Sample & Undigested (total content) & After digestion & Bioaccessible portion & Bioaccessibility (\%) \\
\hline L. rhamnosus yoba jam & $0.68 \pm 0.02^{\mathrm{a}}$ & $0.57 \pm 0.01^{\mathrm{a}}$ & $0.11 \pm 0.01^{\mathrm{a}}$ & $16.1 \pm 0.50^{\mathrm{a}}$ \\
Control & $0.64 \pm 0.03^{\mathrm{b}}$ & $0.55 \pm 0.02^{\mathrm{a}}$ & $0.09 \pm 0.01^{\mathrm{b}}$ & $14.0 \pm 0.33^{\mathrm{b}}$ \\
\hline
\end{tabular}

Mean \pm standard deviations are reported. Means with identical superscripts in a column are not significantly different at $p<0.05$.

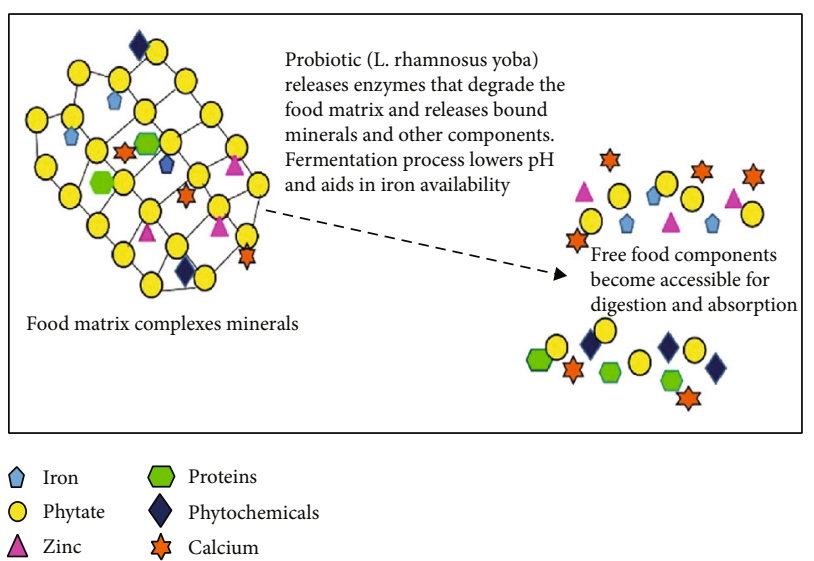

Figure 4: Possible L. rhamnosus yoba mechanism in increased mineral bioaccessibility (adopted from Sripriya et al. [35]).

TABLE 5: Viability of L. rhamnosus yoba and $\mathrm{pH}$ in jam.

\begin{tabular}{lccc}
\hline \multirow{2}{*}{ Time (hours) } & $\begin{array}{c}\text { Viable cells } \\
(\log \text { CFU/mL) }\end{array}$ & Probiotic jam & Control \\
\hline Inoculation: $t=0$ & $5.4 \pm 0.1$ & $3.50 \pm 0.12^{\mathrm{a}}$ & $3.50 \pm 0.12^{\mathrm{a}}$ \\
4 & $5.5 \pm 0.3$ & $3.50 \pm 0.10^{\mathrm{a}}$ & $3.50 \pm 0.10^{\mathrm{a}}$ \\
8 & $5.7 \pm 0.2$ & $3.48 \pm 0.10^{\mathrm{a}}$ & $3.50 \pm 0.10^{\mathrm{a}}$ \\
12 & $5.8 \pm 0.1$ & $3.47 \pm 0.11^{\mathrm{a}}$ & $3.50 \pm 0.01^{\mathrm{a}}$ \\
16 & $5.8 \pm 0.1$ & $3.46 \pm 0.10^{\mathrm{a}}$ & $3.49 \pm 0.01^{\mathrm{b}}$ \\
20 & $6.0 \pm 0.1$ & $3.45 \pm 0.12^{\mathrm{a}}$ & $3.48 \pm 0.01^{\mathrm{b}}$ \\
End of incubation: & $6.2 \pm 0.2$ & $3.45 \pm 0.11^{\mathrm{a}}$ & $3.47 \pm 0.01^{\mathrm{b}}$ \\
$t=24$ & & &
\end{tabular}

Mean \pm standard deviations are reported. Means with identical superscripts in a row are not significantly different at $p<0.05$.

bound minerals in the food matrix. Chawafambira et al. [4] reported a fiber content of $2 \mathrm{~g} / 100 \mathrm{~g}$ in the $U$. kirkiana fruit pulp. Furthermore, L. rhamnosus yoba might have degraded the fiber and released bound minerals in the jam. As the $L$. rhamnosus yoba was fermenting sugars into organic acids, the $\mathrm{pH}$ of the jam decreased to 3.45 and enhanced mineral accessibility. At such a low $\mathrm{pH}$, absorption of iron increases because of the conversion of ferrous iron to ferric iron, which is more bioaccessible and available for absorption [39].

3.3. Enumeration of L. rhamnosus Yoba and $p H$ in Probiotic Jam. Viable counts of L. rhamnosus yoba in the jam were determined at $t=0$ (time of inoculation) and end of incubation period after 24 hours (Table 5). The produced U. kirkiana fruit jam was inoculated with L. rhamnosus yoba at a level of $5.6 \pm 0.1 \log \mathrm{CFU} / \mathrm{mL}$. Mpofu et al. [40] reported an L. rhamnosus yoba level of $5.8 \pm 0.3 \log \mathrm{CFU} / \mathrm{mL}$ in inoculum that was used in the production of probiotic mutandabota. The viable plate count of $L$. rhamnosus yoba increased to $6.2 \pm 0.2 \log \mathrm{CFU} / \mathrm{mL}$ after incubation for $24 \mathrm{~h}$ at $37^{\circ} \mathrm{C}$. This suggests that the jam matrix was an ideal environment to support the growth of $L$. rhamnosus yoba. More so, Wood and Holzapfel [41] reported L. rhamnosus yoba, as a mesophile that grows at a wide temperature range of $15-40^{\circ} \mathrm{C}$. Stadlmayr et al. [8] reported proximate composition of the U. kirkiana fruit pulp on a dry wet basis as water $(72.6 \mathrm{~g} /$ $100 \mathrm{~g})$, crude protein $(0.5 \mathrm{~g} / 100 \mathrm{~g})$, fat $(0.4 \mathrm{~g} / 100 \mathrm{~g})$, ash $(1.1 \mathrm{~g} / 100 \mathrm{~g})$, fiber $(2.3 \mathrm{~g} / 100 \mathrm{~g})$, vitamin C $(16.8 \mathrm{mg} / 100 \mathrm{~g})$, and carbohydrate $(28.7 \mathrm{~g} / 100 \mathrm{~g})$.

The sugars in the fruit pulp plus added table sugar acted as sources of carbon that were apparently enough to support the growth of L. rhamnosus yoba. Ahmed and Mital [42] explained the simulated growth of a related lactic acid bacterium, L. acidophilus, caused by the presence of simple sugars, mainly glucose and fructose, and the minerals manganese and magnesium which are growth promoters. Minerals reported in the $U$. kirkiana fruit pulp ( $\mathrm{mg} / 100 \mathrm{~g} \mathrm{FW}$ ) are iron 11.8 , magnesium 39 , calcium 17 , potassium 375 , sodium 10 , zinc 1.3 , phosphorus 15 , and copper $0.1[4,8,43]$.

The relationship between the jam $\mathrm{pH}$ and storage time is shown in Table 5. At inoculation $(t=0)$, the $\mathrm{pH}$ of the fruit jam was $3.5 \pm 0.12$. This $\mathrm{pH}$ allowed the growth of $L$. rhamnosus yoba in the jam as explained by the increase in cell numbers. The $\mathrm{pH}$ of the inoculated jam decreased with time and reached 3.45 at the end of the incubation period. This decrease in $\mathrm{pH}$ allowed a survival of the L. rhamnosus yoba, but its rate of growth was limited. This supported the growth of $L$. rhamnosus yoba from $5.4 \pm 0.1$ to $6.2 \pm 0.2 \mathrm{log} \mathrm{CFU} / \mathrm{m}$ in the jam. The low $\mathrm{pH}$ could be attributed to citric acid and the presence of naturally occurring organic acids in the fruit 


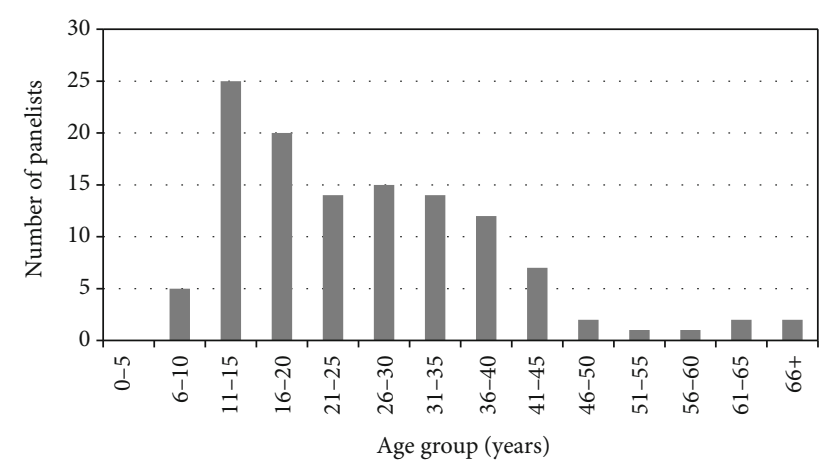

FIgURe 5: Age distribution of panelists.

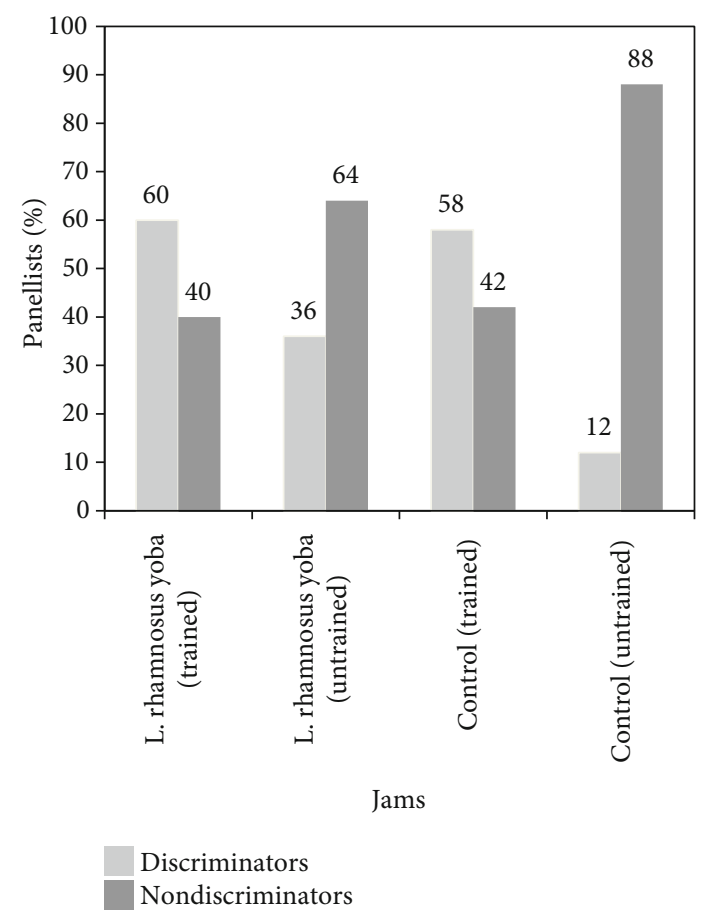

FIGURE 6: Triangle test (discrimination between L. rhamnosus yoba and control jams).

pulp such as citric, malic, tartaric, succinic, and ascorbic acids $[44,45]$. Citric acid is mainly added at a low concentration to balance and improve the $\mathrm{pH}$ in jam making [46]. After $24 \mathrm{~h}$, the $\mathrm{pH}$ had decrease to $3.45 \pm 0.11$. More so, as L. rhamnosus yoba was growing and increasing in cell numbers, it was able to ferment sugars into lactic acid and caused a decrease in $\mathrm{pH}$. The low $\mathrm{pH}$ (3.45) observed in the jam has the potential to inhibit growth of most pathogenic bacteria, thus ensuring a microbiologically safe probiotic jam, although there is need to conduct an assay on the occurrence of pathogenic bacteria in the jam. This is supported by the International Commission on Microbiological Specifications for Foods [47] which reported that at such a low $\mathrm{pH}$ of 3.45 , most pathogens do not survive or grow. Liew et al. [48] indicated that the optimum $\mathrm{pH}$ for growth of L. rhamnosus is $\mathrm{pH} 6.4$ to 6.9. The lowest $\mathrm{pH}$ for growth of the lactic acid bacterium is within the range of $\mathrm{pH}$ 4.4-3.4. Our results for $\mathrm{pH}$ in all jam samples were able to support growth of L. rhamnosus

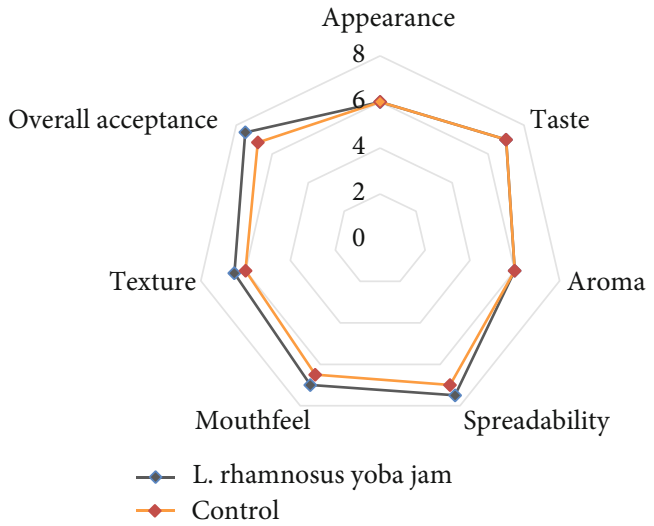

FIgURE 7: Preference test on jam inoculated with L. rhamnosus and control sample.

yoba although they were out of the optimum range for the bacteria. This could be a result of addition of citric acid used to balance the $\mathrm{pH}$ of the jam and promote better gel formation of the jam.

3.4. Demographic Information of Sensory Panelists. The probiotic jam can be consumed by populations of all age groups in rural communities as indicated in Figure 5. Age groups $11-15$ yrs., $16-20$ yrs., and 26-30 yrs. had 25, 20, and 15 panelists, respectively. The age group $66+$ yrs. had 1 participant. The age group 0-5yrs. had no participants because they could not comprehend the sensory evaluation process. The sensory evaluation was performed by panelists with minimum years of 10 . The population distribution in the sample areas indicated that age groups 11-15 and 16-20yrs. were the most common as compared to older ages $[49,50]$. The gender distribution of the panelists was 71 women and 49 men. Rural areas in Zimbabwe have more women than men due to rural exodus, drifting most men to urban areas in search of employment [51].

3.5. Triangle and Preference Test. There was a significant difference $(p<0.05)$ between the trained and untrained panelists with respect to their ability to discriminate the taste of the probiotic and the control jam. Using a triangle test, $60 \%$ and $36 \%$ of the trained and untrained panelist were able to discriminate the probiotic jam, respectively, using taste and appearance. The triangle test showed that $58 \%$ and $12 \%$ of the trained and untrained panelist were able to discriminate the control jam, respectively. Forty percent (40\%) and 74\% of the trained and untrained panelists were unable to discriminate the probiotic jam, respectively (Figure 6). Fortytwo (42\%) percent and $88 \%$ of the trained and untrained panelists were unable to discriminate the control jam, respectively. The panelists that showed the ability to discriminate conducted the paired preference test. The probiotic jam had a mean preference score of 7.5 out of $9,6.5$ out of 9 , and 7 out of 9 for spreadability, texture, and mouth feel, respectively (Figure 7). The mean sensory scores were significantly different using LSD test at the 5\% level. The probiotic jam had an overall acceptance score of 7.5 out of 9 . It was noted that aroma, taste, and appearance were not significantly 
different $(p<0.05)$ in all jam samples. This is supported by the panelist scores for taste, appearance, and aroma (Figure 7). The main sensory descriptors used on the probiotic jam were "a sweet taste" and "excellent spreadability" by over $80 \%$ of the panelists.

There was a significant difference in triangle test results $(p<0.05)$. The trained panelists exhibited a significantly higher success rate of $60 \%$ compared to $40 \%$ for the untrained panelists with respect to correct identification of the probiotic jam. This could be attributed to the fact that the training and experience of the panelists influenced the proper discrimination of the samples during evaluation.

\section{Conclusion}

Lactobacillus rhamnosus yoba was successfully propagated in the $U$. kirkiana fruit jam to produce a probiotic food. The jam had $5.4 \pm 0.1 \log \mathrm{CFU} / \mathrm{mL}$ viable cells on the onset of incubation and $6.2 \pm 0.2 \log \mathrm{CFU} / \mathrm{mL}$ viable $L$. rhamnosus yoba cells on consumption. The fruit jam met the criterion of being a probiotic food because it contained $>6 \mathrm{log}$ $\mathrm{CFU} / \mathrm{mL}$ viable $L$. rhamnosus yoba cells upon consumption with a possibility of promoting health in the human body. Furthermore, the U. kirkiana jam was able to support the growth of L. rhamnosus yoba to a level of $6.2 \mathrm{log} \mathrm{CFU} / \mathrm{mL}$ viable cells on the point of consumption thereby meeting the criteria of being a probiotic food. The probiotic jam (with L. rhamnosus yoba) had an iron bioaccessibility of $6.55 \pm$ $0.36 \%$ and a zinc bioaccessibility of $16.1 \pm 0.50 \%$. The use of $L$. rhamnosus yoba increased iron and zinc bioaccessibility by $4 \%$ and $2 \%$, respectively. The probiotic jam is potentially an excellent source of iron and zinc. The probiotic jam had a low $\mathrm{pH}$ which ensured its microbiological safety although there is need to evaluate its safety. The findings of sensory evaluation indicated that the probiotic jam had good organoleptic properties. A paired difference test showed a significant difference $(p<0.05)$ in jam preferences. More so, the taste of probiotic jam was significantly different from the benchmark sample (mixed fruit jam). The probiotic jam had a higher mean acceptance score of 7.5 using a hedonic rating scale, and this translated to an $83 \%$ acceptance rating by the panelists. The attributes that contributed to a high acceptability of probiotic jam were mouth feel (7.5 out of 9 ), spreadability (7.5 out of 9 ), and texture (6.5 out of 9 ). This study will provide more insights on the need to use L. rhamnosus yoba in fermenting food materials as a way to enhance mineral bioaccessibility. Furthermore, the propagation of $L$. rhamnosus yoba in the fruit creates the need to use other indigenous fruit trees and promote access to beneficial probiotic by most poor populations in sub-Saharan Africa. The study recommends further research on the effect of L. rhamnosus yoba action on inactivation of pathogenic microbes and product shelf life.

\section{Data Availability}

The data of this research is available and will be provided upon request.

\section{Conflicts of Interest}

The authors declare there is no conflict of interest.

\section{Acknowledgments}

The authors would like to thank the Central University of Technology, Free State, Research and Development (Grant award number RGS/2018) for financial assistance. We would like to thank SAZ and Chinhoyi University of Technology, Department of Food Science and Technology, for assistance with their laboratories. The participation by local households in Gokwe, Bikita, and Kazangarare is greatly appreciated.

\section{References}

[1] World Agroforesty Centre, "Uapaca kirkiana - its uses, ecology, identity, propagation, pests," World Agroforesty Centre. Retrieved, 2020, May 24, from http://www.worldagroforestry .org/.

[2] Ecocrop database, "An excellent guide to the plants data," Ecocrop. Retrieved 2020, May 24, from http://ecocrop.fao.org/ ecocrop/srv/en/home.

[3] P. Bille, M. Shikongo-Nambab, and A. Cheikhyoussef, "Value addition and processed products of three indigenous fruits in Namibia," African Journal of Food, Agriculture, Nutrition and Development, vol. 13, pp. 7192-7212, 2013.

[4] A. Chawafambira, M. M. Sedibe, A. Mpofu, and M. Achilonu, "Uapaca kirkiana, an indigenous fruit tree in sub-Saharan Africa: a comprehensive review," Cogent Food \& Agriculture, vol. 6, no. 1, article 1766735, 2020.

[5] F. K. Akinnifesi, R. R. B. Leakey, O. Ajayi et al., Indigenous Fruit Trees in the Tropics: Domestication, Utilization and Commercialization, CABI, Wallingford, UK, 2008.

[6] B. K. Ndabikunze, B. N. Masambu, and B. M. Tiisekwa, "Vitamin $C$ and mineral contents, acceptability and shelf life of juice prepared from four indigenous fruits of the Miombo woodlands of Tanzania," Journal of Food, Agriculture and Environment, vol. 8, pp. 91-96, 2010.

[7] B. Vinceti, A. Ickowitz, B. Powell et al., "The contributions of forest foods to sustainable diets," Unasylvia, vol. 4, no. 241, pp. 54-64, 2013.

[8] B. Stadlmayr, U. R. Charrondiere, S. Eisenwagen, R. Jamnadass, and K. Kehlenbeck, "Nutrient composition of selected indigenous fruits from sub-Saharan Africa," Journal of The Science Of Food And Agriculture, vol. 93, pp. 26272636, 2013.

[9] E. Fernandez-Garcia, I. Carvajal-Lerida, and A. Perez-Galvez, "In vitro bioaccessibility assessment as a prediction tool of nutritional efficiency," Nutrition Research, vol. 29, no. 11, pp. 751-760, 2009.

[10] S. Rousseau, S. Kyomugasho, C. Kyomugasho, M. Celus, M. E. G. Hendrickx, and T. Grauwet, "Barriers impairing mineral bioaccessibility and bioavailability in plant-based foods and the perspectives for food processing," Critical Reviews in Food Science and Nutrition, vol. 60, no. 5, pp. 826-843, 2020.

[11] A. Brodkorb, L. Egger, M. Alminger et al., "INFOGEST static in vitro simulation of gastrointestinal food digestion," Nature Protocols, vol. 14, 2019. 
[12] K. Platel and K. Srinivasan, "Bioavailability of micronutrients from plant foods: an update," Critical Reviews in Food Science and Nutrition, vol. 56, no. 10, pp. 1608-1619, 2015.

[13] Y. Pranoto, S. Anggrahini, and Z. Efendi, "Effect of natural and Lactobacillus plantarum fermentation on in-vitro protein and starch digestibilities of sorghum flours," Food Bioscience, vol. 2, pp. 46-52, 2013.

[14] A. Cilla, M. J. Garcia-Nebot, S. Perales, M. J. Lagarda, R. Barbera, and R. Farre, "In vitro bioaccessibility of iron and zinc in fortified fruit beverages," International Journal of Food Science And Technology, vol. 44, no. 6, pp. 1088-1092, 2009.

[15] A. Q. Truong-Tran, L. H. Ho, F. Chai, and P. D. Zalewski, "Cellular zinc fluxes and the regulation of apoptosis/genedirected cell death," Journal of Nutrition, vol. 130, no. 5, pp. 1459S-1466S, 2000.

[16] M. D. Sitrin, "Absorption of water-soluble vitamins and minerals," in The Gastrointestinal System, P. S. Leung, Ed., pp. 211-234, Springer, Netherlands, 2014.

[17] K. Parvaneh, R. Jamaluddin, G. Karimi, and R. Erfani, "Effect of probiotics supplementation on bone mineral content and bone mass density," Scientific World Journal, vol. 127, pp. 16, 2014, Hindawi Publishing Corporation.

[18] M. L. Villa, R. Marcus, D. R. J. Ramírez, and L. Kelsey, "Factors contributing to skeletal health of postmenopausal MexicanAmerican women," Journal of Bone and Mineral Research, vol. 10, no. 8, pp. 1233-1242, 1995.

[19] S. Guandalini, L. Pensabene, M. A. Zikri et al., "Lactobacillus GG administered in oral rehydration solution to children with acute diarrhea: a multicenter European trial," Journal of Pediatric Gastroenterology and Nutrition, vol. 30, no. 1, pp. 54-60, 2000.

[20] I. Hojsak, N. Snovak, S. Abdovic, H. Szajewska, Z. Misak, and S. Kolacek, "Lactobacillus GG in the prevention of gastrointestinal and respiratory tract infections in children who attend day care centers: a randomized, double-blind, placebocontrolled trial," Clinical Nutrition, vol. 29, no. 3, pp. 312316, 2010.

[21] R. Kort and W. Sybesma, "Probiotics for every body," Trends Biotechnology, vol. 30, no. 12, pp. 613-615, 2012.

[22] T. Mattila-Sandholm, P. Myllärinen, R. Crittenden, G. Mogensen, R. Fondén, and M. Saarela, "Technological challenges for future probiotic foods," International Dairy Journal, vol. 12, no. 2-3, pp. 173-182, 2002.

[23] M. Minekus, M. Alminger, P. Alvito et al., "A standardised static in vitro digestion method suitable for food - an international consensus," Food and Function, vol. 5, no. 6, pp. 11131124, 2014.

[24] AOAC, Official Methods of Analysis of the Association of Official Analytical Chemists, AOAC International, Gaithersburg, MD, 18th edition, 2005.

[25] S. Hemalatha, K. Platel, and K. Srinivasan, "Zinc and iron contents and their bioaccessibility in cereals and pulses consumed in India," Food Chemistry, vol. 102, no. 4, pp. 1328-1336, 2007.

[26] Association of Official Analytical Chemistry, Official Method of Analysis (AOAC) International, AOAC International, Maryland, USA, 17th edition, 2000.

[27] R. B. Khouzam, P. Pohl, and R. Lobinski, "Bioaccessibility of essential elements from white cheese, bread, fruit and vegetables," Talanta, vol. 86, pp. 425-428, 2011.

[28] U. Schlemmer, W. Frølich, R. M. Prieto, and F. Grases, "Phytate in foods and significance for humans: food sources, intake, processing, bioavailability, protective role and analysis," Molecular Nutrition \& Food Research, vol. 53, no. S2, pp. S330-S375, 2009.

[29] R. S. Gibson, V. Raboy, and J. C. King, "Implications of phytate in plant-based foods for iron and zinc bioavailability, setting dietary requirements, and formulating programs and policies," Nutrition Reviews, vol. 76, no. 11, pp. 793-804, 2018.

[30] A. Chawafambira, M. M. Sedibe, A. Mpofu, and M. Achilonu, "Bioactive compounds and functional potential of Uapaca kirkiana (Muell. Arg.) fruits," African Journal of Food, Agriculture, Nutrition \& Development, vol. 20, no. 5, pp. 1649016508, 2020.

[31] N. Roohani, R. Hurrell, R. Kelishadi, and R. Schulin, "Zinc and its importance for human health: an integrative review," Journal of Research in Medical Sciences: The Official Journal of Isfahan University of Medical Sciences, vol. 18, no. 2, pp. 144-157, 2013.

[32] Zimbabwe Demographic and Health Survey (ZDHS), Key Indicators, Zimbabwe National Statistics Agency (ZIMSTAT) and ICF International, Rockville, Maryland, USA, 2016.

[33] P. Etcheverry, M. A. Grusak, and L. E. Fleige, "Application of in vitro bioaccessibility and bioavailability methods for calcium, carotenoids, folate, iron, magnesium, polyphenols, zinc, and vitamins B6, B12, D, and E," Frontiers in Physiology, vol. 3, p. 317, 2012.

[34] M. K. Hambidge, L. V. Miller, J. E. Westcott, X. Sheng, and N. F. Krebs, "Zinc bioavailability and homeostasis," American Journal of Clinical Nutrition, vol. 91, no. 5, pp. 1478S-1483S, 2010.

[35] G. Sripriya, U. Antony, and T. S. Chandra, "Changes in carbohydrate, free amino acids, phytate and $\mathrm{HCl}$ extractability of minerals during germination and fermentation of finger millet (Eleusine coracana)," Food Chemistry, vol. 58, pp. 345-350, 1997.

[36] C. N. Day and R. O. Morawicki, "Effects of fermentation by yeast and amylolytic lactic acid bacteria on grain sorghum protein content and digestibility," Journal of Food Quality, vol. 2018, 8 pages, 2018.

[37] Y. Lopez, D. T. Gordon, and M. L. Fields, "Release of phosphorous from phytate by natural lactic fermentation," Journal of Food Science, vol. 48, pp. 935-954, 1983.

[38] J. Liang, B. Z. Han, M. J. R. Nout, and R. J. Hamer, "Effects of soaking, germination and fermentation on phytic acid, total and in vitro soluble zinc in brown rice," Food Chemistry, vol. 110, pp. 821-828, 2008.

[39] A. Khalighi, R. Behdani, and S. Kouhestani, "Probiotics: a comprehensive review of their classification, mode of action and role in human nutrition," Probiotics and Prebiotics in Human Nutrition and Health, vol. 10, article 63646, 2016.

[40] A. Mpofu, A. R. Linnemann, W. Sybesma, R. Kort, M. J. Nout, and E. J. Smid, "Development of a locally sustainable functional food based on mutandabota, a traditional food in southern Africa," Journal of Dairy Science, vol. 97, pp. 2591-2599, 2014.

[41] B. J. B. Wood and W. H. Holzapfel, "Genera of lactic acid bacteria," Blackie Academic and Professional, London, UK, 1995.

[42] B. Ahmed and B. K. Mital, "Effects of magnesium and manganese ions on the growth of Lactobacillus acidophilus," Journal of Food Science and Technology, vol. 27, pp. 228-229, 1990.

[43] F. Malaisse and G. Parent, "Edible wild vegetable products in the Zambezian woodland area: a nutritional and ecological 
approach," Ecology of Food and Nutrition, vol. 18, pp. 43-82, 2010.

[44] S. Vertuani, E. Braccioli, V. Buzzoni, and S. Manfredini, "Antioxidant capacity of Adansonia digitata fruit pulp and leaves," Acta Phytotherapeutica, vol. 2, pp. 2-7, 2002.

[45] A. Mpofu, A. R. Linnemann, M. J. R. Nout, H. M. Zwietering, and E. J. Smid, "Mutandabota, a food product from Zimbabwe: processing, composition, and socioeconomic aspects, composition, and socioeconomic aspects," Ecology of Food and Nutrition, vol. 53, no. 1, pp. 24-41, 2014.

[46] S. A. Featherstone, "A complete course in canning and related processes - processing procedures for canned food products," in Series in food science, technology and nutrition, Woodhead publishing, 14th edition, 2016.

[47] International Commission on Microbiological Specifications for Foods, Microbiological testing in food safety management - microorganisms in food 7, Springer Science, New York, USA, 2002.

[48] S. L. Liew, A. B. Ariff, A. R. Raha, and Y. W. Ho, "Optimization of medium composition for the production of a probiotic microorganism, Lactobacillus rhamnosus, using response surface methodology," International Journal of Food Microbiology, vol. 102, pp. 137-142, 2005.

[49] Zimbabwe National Statistics Agency (ZIMSTAT) and ICF International, Zimbabwe Demographic and Health Survey 2010-11, ZIMSTAT and ICF International Inc. USA, Calverton, Maryland, 2012.

[50] WHO, World Health Statistics 2013 - Indicator Compendium, World Health Organization, Geneva, Switzerland, 2013.

[51] F. Olivieri, S. Semproli, D. Pettener, and S. Toselli, "Growth and malnutrition of rural Zimbabwean children (6-17 years of age)," American Journal of Physical Anthropology, vol. 136, no. 2, pp. 214-222, 2008. 